\title{
EFEKTIVITAS PENERAPAN METODE TALKING STICK DALAM PEMBELAJARAN KETERAMPILAN MENULIS TEKS TANGGAPAN KRITIS
}

\author{
Andriani*, Fausiah
}

\begin{abstract}
The background of this research is due to the lack of ability to write learners in Indonesian language learning, especially in writing critical response text. This research is an experimental research that aims to get an idea of the effectiveness or not of the learning method of talking stick in the Indonesian language lesson, especially writing the text of critical responses in class IX students of SMP Negeri 6 Wonomulyo. Based on the result of the research, using descriptive statistical analysis for the instrument in the form of the result of the pretest learning test of class IX D as experiment class before the application of the talking stick method obtained an average value of $2.33 \%$ and after the application of talking stick method in learning writing critical text responses the average posttest score increased by $3.20 \%$. While in class IX $B$ as control class pretest average value of $2.22 \%$ and after the use of conventional methods final or posttest test results average value of $2.91 \%$. Result of inferential statistic analysis for hypothesis test by using Independent Samples Test obtained sig value $0,312>0,05$, so $H_{0}$ rejected. From the results of this study can be concluded that there are differences of learners who were taught by using conventional methods and learners who are given special treatment by applying the talking stick method, in this case it is known that Indonesian language learning with talking stick method is effective compared to learning Indonesian language with conventional method (not given treatment).
\end{abstract}

Keywords: Effectiveness, talking stick method, Writing Skill.

\section{PENDAHULUAN}

Kedudukan bahasa Indonesia dalam kurikulum 2013 sangat penting karena seorang guru harus mampu mengajar bahasa Indonesia kepada peserta didik secara utuh, maksudnya bahasa Indonesia tidak hanya diajarkan sebagai alat komunikasi tetapi bahasa sebagai alat politik identitas. Pelajaran bahasa Indonesia dianggap penting karena bahasa Indonesia terdapat disetiap sisi

*) Prodi Pendidikan Bahasa Indonesia, Universitas Al Asyariah Mandar, E-mail:andriani.ani2929@gmail.com 
alat komunikasi tetapi bahasa sebagai alat politik identitas. Pelajaran bahasa Indonesia dianggap penting karena bahasa Indonesia terdapat disetiap sisi kehidupan. Mensyukuri anugerah Tuhan akan keberadaan bahasa Indonesia dan menggunakannya sesuai dengan kaidah dan konteks untuk mempersatukan bangsa. Dibanding mata pelajaran lain, pembelajaran bahasa Indonesia pada hakikatnya adalah membelajarkan peserta didik tentang keterampilan berbahasa Indonesia yang baik dan benar sesuai tujuan dan fungsinya. Mata pelajaran bahasa Indonesia bertujuan agar peserta didik memiliki kemampuan berkomunikasi secara efektif dan efisien sesuai dengan etika yang berlaku, baik secara lisan maupun tulis.

Pada kurikulum 2013, keempat aspek keterampilan berbahasa tidak disebutkan secara eksplisit. Namun, sudah mencakup secara keseluruhan melalui pembelajaran berbasis teks bermuara pada keterampilan menulis. Dengan berbasis teks, siswa menggunakan bahasa tidak saja hanya dijadikan sebagai sarana komunikasi, tetapi sebagai sarana mengembangkan kemampuan berfikir. Misalnya, keterampilan menulis teks dalam bentuk teks tanggapan kritis merupakan kompetensi dasar yang terdapat dalam kurikulum 2013. Penuangan ide tidak terjadi begitu saja tanpa suatu proses dan latihan dalam mengungkapkan ide yang ada dalam pikiran peserta didik.

Adapun empat keterampilan berbahasa yang harus diketahui, yaitu membaca, mendengarkan, berbicara dan menulis. Keterampilan berbahasa ini sudah termaktub dalam kurikulum pembelajaran. Oleh karena itu, setiap keterampilan itu erat hubungannya dengan proses-proses yang mendasari bahasa. Bahasa seseorang mencerminkan pikirannya. Semakin terampil seseorang berbahasa, semakin cerah dan jelas pula jalan pikirannya. Keterampilan berbahasa hanya dapat diperoleh dan dikuasai dengan jalan praktik dan banyak latihan.

Berdasarkan observasi yang dilakukan peneliti serta informasi yang telah di dapatkan dari guru bahasa Indonesia di SMP Negeri 6 Wonomulyo, permasalahan yang dialami peserta didik tersebut adalah pembelajaran bahasa Indonesia itu sendiri. Karena pembelajaran bahasa juga bukan hal yang patut diremehkan, dengan kata lain pembelajaran bahasa termasuk pembelajaran yang susah. Hal ini terbukti karena masih banyak peserta didik yang tidak mampu mencapai nilai KKM bahasa Indonesia yang seharusnya 2,67.

Berdasarkan uraian pada latar belakang, peneliti tertarik melakukan penelitian dengan judul "Efektivitas Penerapan Metode Talking Stick dalam Pembelajaran Keterampilan Menulis Teks Tanggapan Kritis Kelas IX SMP Negeri 6 Wonomulyo Kabupaten Polewali Mandar". 
Masalah penelitian ini adalah bagaimanakah efektivitas penerapan metode talking stick dalam pembelajaran keterampilan menulis teks tanggapan kritis kelas IX SMP Negeri 6 Wonomulyo Kabupaten Polewali Mandar dan tujuan dari penelitian ini untuk mengetahui efektivitas penerapan metode talking stick dalam pembelajaran keterampilan menulis teks tanggapan kritis kelas IX SMP Negeri 6 Wonomulyo Kabupaten Polewali Mandar.

Menulis merupakan sebuah proses kreatif menuangkan gagasan dalam bentuk bahasa tulis dalam tujuan, misalnya memberitahu, meyakinkan, atau menghibur. Hasil dari proses kreatif ini biasa disebut dengan istilah karangan atau tulisan. Kedua istilah tersebut mengacu pada hasil yang sama meskipun ada pendapat yang mengatakan kedua istilah tersebut memiliki pengertian yang berbeda. Istilah menulis sering melekatkan pada proses kreatif yang sejenis ilmiah. Sementara istilah mengarang sering dilekatkan pada proses kreatif yang berjenis nonilmiah. (Dalman, H, 2015: 03). Alwi (2001:121) menyatakan, menulis adalah melahirkan pikiran atau perasaan dengan tulisan. Sementara Tarigan (2008: 22) mengemukakah bahwa menulis adalah menurunkan atau melukiskan lambang-lambang grafik yang menggambarkan suatu bahasa yang dipahami oleh seseorang, sehingga orang lain dapat membaca lambang-lambang grafik tersebut kalau mereka memahami bahasa dan gambaran grafik itu.

Menurut Iskandarwassid dan Sunendar (2008: 248), menulis adalah usaha untuk mengungkapkan pikiran dan perasaan yang ada pada diri seorang pemakai bahasa melalui bahasa dan penyampaian pesan diungkapkan secara tertulis. Selanjutnya Ambo Enre (1994: 3) berpendapat bahwa menulis adalah alat yang sangat ampuh dalam belajar yang dengan sendirinya memainkan peran yang sangat penting dalam dunia pendidikan. Zainurrahman (2011: 5) mengemukakan bahwa menulis dalam konteks formal merupakan aktivitas berbahasa yang paling fleksibel. Artinya menulis memiliki struktur wajib yang tidak boleh diubah secara arbitrer. Semua jenis tulisan formal memiliki format tersendiri, paten, dan permanen. Format dari tulisan dalam konteks formal ditentukan oleh sejumlah kesepakatan atau konvensi masyarakat pengguna tulisan tersebut.

Metode talking stick adalah proses pembelajaran dengan bantuan tongkat yang berfungsi sebagai alat untuk menentukan peserta didik yang akan menjawab pertanyaan. Pembelajaran dengan metode talking stick bertujuan untuk mendorong peserta didik agar berani mengemukakan pendapat. metode pembelajaran talking stick dalam proses belajar mengajar di kelas berorientasi pada terciptanya kondisi belajar melalui permainan tongkat yang diberikan dari satu peserta didik kepada peserta didik yang lainnya. Tongkat digulirkan dengan 
diiringi musik. Pada saat musik berhenti maka peserta didik yang sedang memegang tongkat itulah yang memperoleh kesempatan untuk menjawab pertanyaan tersebut.

Langkah pembelajaran ini adalah guru menyiapkan tongkat, sajian materi pokok, peserta didik membaca materi lengkap pada wacana, guru mengambil tongkat dan memberikan tongkat kepada peserta didik dan peserta didik yang kebagian tongkat menjawab pertanyaan dari guru, tongkat diberikan kepada peserta didik lain dan guru memberikan pertanyaan lagi dan seterusnya (Djumingin, Sulastriningsih, 2011:176).

Teks tanggapan kritis adalah teks yang berisi kritik tajam atau kritikan pedas terhadap suatu hal yang mengenai kesalahan. Umumnya penggunaan teks ini yaitu pada event atau acara debat di suatu forum. Seseorang dituntut untuk bisa menganalisis suatu pendapat dan juga harus menerima semua kritikan atau tanggapan dari seorang teman atau orang lain karena dibalik kritikan pasti ada alasan yang mendasari hal tersebut dan demi kebaikan seseorang itu sendiri

\section{METODE PENELITIAN}

Jenis penelitian yang digunakan oleh peneliti adalah jenis penelitian eksperimen. Dimana penelitian ini menggunakan dua kelas yakni kelas eksperimen dan kelas kontrol. Tempat penelitian SMP Negeri 6 Wonomulyo Jalan Poros Pulliwa, Kecamatan Bulo Kabupaten Polewali Mandar. Penelitian ini akan dilaksanakan pada bulan November 2016.

Adapun yang menjadi populasi dalam penelitian ini adalah keseluruhan peserta didik kelas IX SMP Negeri 6 Wonomulyo dan yang menjadi sampel penelitian ini adalah kelas IX B dan IX D.

Penelitian ini menggunakan dua instrumen penelitian, yakni instrumen tes dan nontes. Instrumen tes yang digunakan dalam penelitian ini adalah pretes dan postes mengenai kemampuan menulis teks tanggapan kritis peserta didik. Instrumen nontes yang dalam penelitian ini adalah teknik observasi dan dokumentasi.

Dalam menyelesaikan penelitian ini, teknik pengumpulan data yang digunakan yaitu teknik tes dan nontes. Analisis data penelitian ini, penulis menggunakan teknik analisis data kualitatif dan analisis data kuantitatif. Data kualitatif adalah data yang berbentuk kata-kata, misalnya wawancara, dokumentasi, serta hasil observasi di lapangan. Analisis data kuantitatif adalah analisis data yang berupa angka-angka. Tujuan dari analisis ini adalah untuk memahami apa yang terdapat dibalik dan meringkasnya menjadi rumusan yang mudah untuk dimengerti. 


\section{HASIL DAN PEMBAHASAN}

Berikut disajikan kedalam tabel hasil analisis Pre-test kelas kontrol dan kelas eksperimen serta hasil analisis Post-test kelas kontrol dan kelas eksperimen. Tabel 1. Distribusi Frekuensi dan Persentase Pree-test Kelas Kontrol.

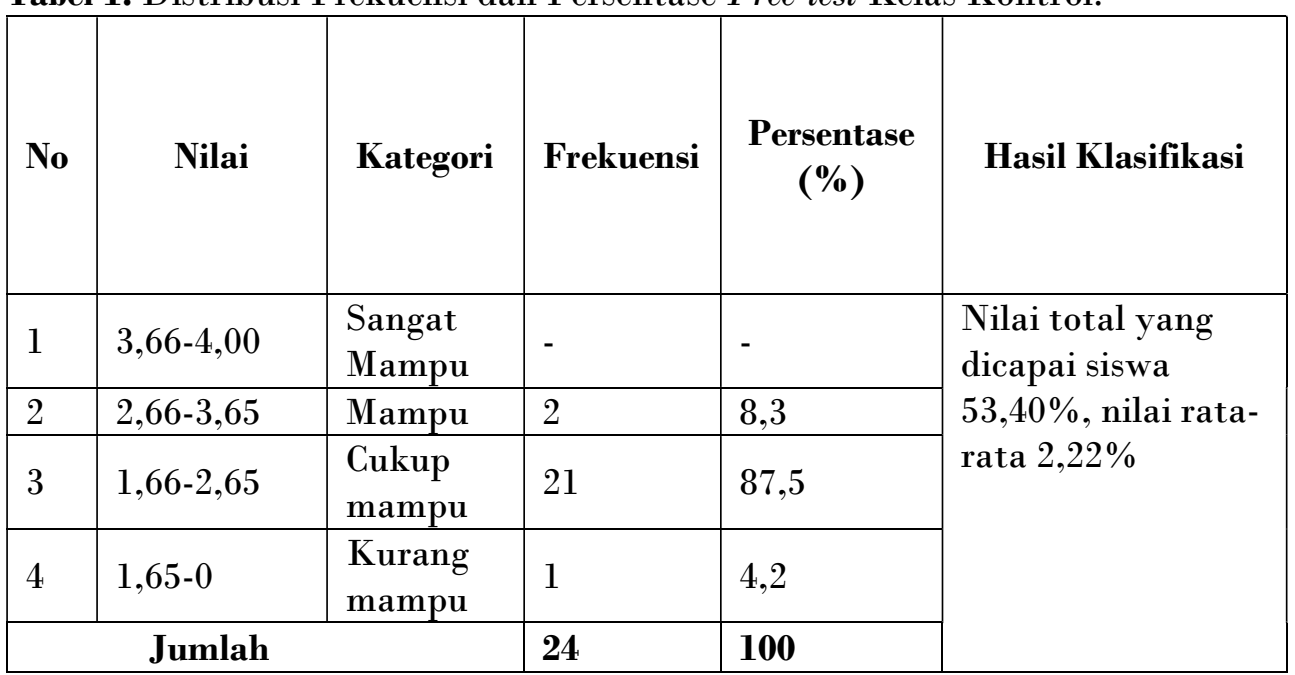

Berdasarkan pada tabel 1 diatas dapat dijelaskan bahwa terdapat 24 peserta didik yang mengikuti tes awal pelajaran pada pelaksanaan tes awal (pree-test). Terdapat 1 orang atau sebesar $4,2 \%$ yang berada pada kategori nilai kurang mampu, dalam kategori cukup mampu sebanyak 21 orang atau sebesar $87,5 \%$, sedangkan kategori mampu sebanyak 2 orang atau sebesar 8,3\% dari 24 peserta didik dari skor ideal sebesar $100 \%$. Adapun hasil tes yang diperoleh peserta didik kelas IX SMP Negeri 6 Wonomulyo terhadap keseluruhan aspek yang dinilai total 53,40 dengan nilai rata-rata $2,22 \%$ dimana berada pada kategori cukup mampu.

Tabel 2. Distribusi Frekuensi dan Persentase Pos-test Kelas Kontrol

\begin{tabular}{|c|c|c|c|c|c|}
\hline No & Nilai & Kategori & $\mathbf{F}$ & $\begin{array}{c}\text { Persentase } \\
(\%)\end{array}$ & Hasil Klasifikasi \\
\hline 1 & $3,66-4,00$ & Sangat Mampu & - & - & \multirow{5}{*}{$\begin{array}{l}\text { Nilai total yang } \\
\text { dicapai } \\
70,00 \% \text {, nilai rata- } \\
\text { rata } 2,91 \%\end{array}$} \\
\hline 2 & $2,66-3,65$ & Mampu & 13 & 54,16 & \\
\hline 3 & $1,66-2,65$ & Cukup mampu & 9 & 37,5 & \\
\hline 4 & $1,65-0$ & $\begin{array}{l}\text { Kurang } \\
\text { mampu }\end{array}$ & 2 & 8,33 & \\
\hline \multicolumn{3}{|c|}{ Jumlah } & 24 & 100 & \\
\hline
\end{tabular}


Berdasarkan pada tabel 2 diatas dapat dijelaskan bahwa terdapat 24 peserta didik yang mengikuti tes akhir pelajaran pada pelaksanaan tes akhir (pos-test). Terdapat 1 orang atau sebesar $4,17 \%$ yang berada pada kategori nilai sangat mampu, dalam kategori mampu sebanyak 12 orang atau sebesar $50 \%$, sedangkan kategori cukup mampu sebanyak 9 orang atau sebesar $37,5 \%$, dan dalam kategori kurang mampu sebanyak 2 orang atau sebesar 8,33\% dari 24 peserta didik dari skor ideal sebesar $100 \%$. Adapun hasil tes yang diperoleh peserta didik kelas IX SMP Negeri 6 Wonomulyo terhadap keseluruhan aspek yang dinilai total 70,00 dengan nilai rata-rata $2,91 \%$ dimana berada pada kategori mampu.

Tabel 3. Distribusi Frekuensi dan Persentase Pree-test Kelas Eksperimen

\begin{tabular}{|c|c|c|c|c|c|}
\hline No & Nilai & Kategori & $\mathbf{F}$ & $\begin{array}{c}\text { Persentase } \\
(\%)\end{array}$ & Hasil Klasifikasi \\
\hline 1 & $3,66-4,00$ & Sangat Mampu & - & - & \multirow{5}{*}{$\begin{array}{l}\text { Nilai total yang } \\
\text { dicapai siswa } \\
56,00 \% \text {, nilai rata- } \\
\text { rata } 2,33 \%\end{array}$} \\
\hline 2 & $2,66-3,65$ & Mampu & 1 & 4,16 & \\
\hline 3 & $1,66-2,65$ & Cukup mampu & 20 & 83,33 & \\
\hline 4 & $0,0-1,65$ & $\begin{array}{l}\text { Kurang } \\
\text { mampu }\end{array}$ & 3 & 12,5 & \\
\hline \multicolumn{3}{|c|}{ Jumlah } & 24 & 100 & \\
\hline
\end{tabular}

Berdasarkan data pada tabel 3 maka dapat dijelaskan bahwa hasil tes yang diperoleh peserta didik kelas eksperimen melalui pree-test terhadap keseluruhan aspek yang dinilai mencapai nilai total 56,00 dengan nilai rata-rata $2,33 \%$ dan dalam kategori cukup mampu.

Dari 24 peserta didik, terdapat 1 peserta didik yang berada pada nilai $(2,66-3,65)$ dalam kategori mampu dengan jumlah persentase 4,16\%, 20 peserta didik berada pada nilia $(1,66-2,65)$ dalam kategori cukup mampu dengan jumlah persentase $83,33 \%$, dan 3 peserta didik berada pada nilai $(0,0-1,65)$ dalam kategori kurang mampu dengan jumlah persentase 12,5\%. Dengan demikian, secara umum peserta didik dalam kategori cukup mampu menulis teks tanggapan kritis.

Tabel 4. Distribusi Frekuensi dan Persentase Pos-test Kelas Eksperimen

\begin{tabular}{|c|c|c|c|c|c|}
\hline No & Nilai & Kategori & $\mathbf{F}$ & $\begin{array}{c}\text { Persentase } \\
(\%)\end{array}$ & Hasil Klasifikasi \\
\hline 1 & $3,66-4,00$ & Sangat Mampu & 1 & 4,16 & \multirow{4}{*}{$\begin{array}{l}\text { Nilai total yang } \\
\text { dicapai siswa } 76,80 \% \text {, } \\
\text { nilai rata-rata } 3,2 \%\end{array}$} \\
\hline 2 & $2,66-3,65$ & Mampu & 21 & 87,5 & \\
\hline 3 & $1,66-2,65$ & Cukup mampu & 2 & 8,33 & \\
\hline 4 & $0,0-1,65$ & $\begin{array}{l}\text { Kurang } \\
\text { mampu }\end{array}$ & - & - & \\
\hline
\end{tabular}




\section{\begin{tabular}{l|l|l|} 
Jumlah & 24 & 100 \\
\hline
\end{tabular}}

Berdasarkan data pada tabel 4.maka dapat dijelaskan bahwa hasil tes yang diperoleh peserta didik kelas IX D melalui pos-test terhadap keseluruhan aspek yang dinilai mencapai nilai total 76,80 dengan nilai rata-rata 3,2 dan dalam kategori mampu.

Dari 24 peserta didik, terdapat 1 peserta didik yang berada pada nilai $(3,66-4,00)$ dalam kategori sangat mampu dengan jumlah persentase 4,16\%, 16 peserta didik berada pada nilai $(2,66-3,65)$ dalam kategori mampu dengan jumlah persentase $87,5 \%$, dan 2 peserta didik berada pada nilai $(1,66-2,65)$ dalam kategori cukup mampu dengan jumlah persentase 8,33\%. Dengan demikian, secara umum peserta didik dalam kategori mampu menulis teks tanggapan kritis.

Penelitian yang diawali dengan pemberian tes awal (pree-test) pada kedua kelompok untuk melihat kemampuan awal peserta didik sebelum proses pembelajaran, setelah itu deberikan materi pelajaran kepada kedua kelompok peserta didik, yakni kelas eksperimen dan kelas kontrol. Perbedaanya, kelas eksperimen menggunakan metode talking stick dalam pembelajarannya sedangkan kelas kontrol juga melakukan proses pembelajaran, hanya saja tidak menggunakan metode talking stick dalam proses pembelajaran seperti kelas eksperimen. Setelah proses ppembelajaran dalam beberapa kali pertemuan diberikan post-test atau tes akhir pada kedua kelompok guna ingin melihat perbandingan hasil tes belajar dari kedua kelompok tersebut.

Setelah proses penelitian dilakukan, menghasilkan beberapa penemuanpenemuan yang menyatakan bahwa:

Berdasarkan hasil observasi awal nilai KKM yang diterapkan pada sekolah SMP Negeri 6 Wonomulyo pada mata pelajaran Bahasa Indonesia adalah 2,67. Hasil analisis data yang telah diperoleh dalam penelitian ini, maka dapat disimpulkan bahwa penggunaan metode talking stick dalam proses pembelajaran dapat mempengaruhi kemampuan menulis teks tanggapan kritis peserta didik SMP Negeri 6 Wonomulyo, perhitungan yang telah diuraikan dalam analisis menggunakan SPSS, dapat dikemukakan rata-rata kelompok kontrol melalui pree-test yaitu 2,22 dan kelompok eksperimen melalui pree-test yaitu 2,33. Data kedua kelompok melalui pree-test atau tes awal berdistribusi normal dan berasal dari populasi yang sama atau homogen yaitu peserta didik SMP Negeri 6 Wonomulyo.

Pada hasil analisis perhitungan seperti telah diuraikan, dapat dikemukakan rata-rata kelompok kontrol melalui post-test yaitu 2,91 dan kelompok ekperimen melalui post-test yaitu 3,20. Data kedua kelompok melalui post-test berdistribusi normal dan berasal dari populasi yang sama atau homogen 
yaitu SMP Negeri 6 Wonomulyo. Nilai rata-rata post-test peserta didik kelas kontrol dan kelas ekperimen terdapat perbedaan. Kelas eksperimen yang diberi perlakuan dengan menggunakan metode talking stick dalam pembelajan nilai post-tesnya lebih tinggi jika dibandingkan dengan tidak menggunakan metode talking stick. Kemudian berdasarkan analisis perhitungan pada pengujian homogenitas varians diperoleh bahwa $t_{\text {hitung }}$ sebesar 2539 dan nilai $t_{\text {tabel }}$ adalah sebesar 2,02. Hal ini menunjukkan bahwa data nilai hasil post-test peserta didik untuk kedua kelompok perlakuan berasal dari populasi yang homogen atau dapat disimpulkan bahwa variansi kedua kelompok data, yaitu kelas ekperimen dan kelas kontrol adalah sama atau homogen.

Menurut pengamatan peneliti, hal ini disebabkan oleh proses penerimaan peserta didik terhadap mata pelajaran yang diberikan lebih berkesan serta peserta didik juga dapat mengamati dan memperhatikan apa yang diperlihatkan oleh seorang guru selama pelajaran berlangsung, sehingga pusat perhatian peserta didik berpusat pada materi pelajaran yang diberikan dan mudah dimengerti oleh peserta didik dengan tidak menggunakan metode pembelajaran talking stick.

Berdasarkan aktivitas peserta didik di kelas eksperimen lebih baik dibandingkan dengan kelas kontrol dan hasil observasi selama proses pembelajaran, peserta didik umumnya bersemangat dan termotivasi dengan metode pembelajaran talking stick. Metode pembelajaran talking stick adalah proses pembelajaran dengan bantuan tongkat yang berfungsi sebagai alat untuk menentukan peserta didik yang akan menjawab pertanyaan. Pembelajaran dengan metode talking stick bertujuan untuk mendorong peserta didik agar berani mengemukakan pendapat. Sehingga peserta didik tidak merasa bosan atau jenuh, hal tersebut terjadi ketika peserta didik tidak menyadari waktu pelajaran telah selesai.

\section{SIMPULAN}

Berdasarkan hasil observasi awal nilai KKM yang diterapkan pada sekolah SMP Negeri 6 Wonomulyo pada mata pelajaran Bahasa Indonesia adalah 2,67. Hasil analisis data yang telah diperoleh dalam penelitian, maka dapat disimpulkan bahwa penggunaan metode pembelajaran talking stick dapat mempengaruhi kemampuan menulis teks tanggapan kritis peserta didik kelas IX SMP Negeri 6 Wonomulyo, dengan lebih memahami struktur teks tanggapan kritis, isi teks tanggapan dan cara menulis teks tanggapan kritis. Hal ini dibuktikan: 
1. Nilai rata-rata yang dicapai peserta didik kelas IX B yang bertindak selaku (kelas kontrol) yang tidak menggunakan metode pembelajaran talking stick pada tes awal adalah 2,22 dalam kategori cukup dan tes akhir adalah 2,91 dalam kategori mampu.

2. Nilai rata-rata yang dicapai peserta didik kelas IX D yang bertindak sebagai (kelompok eksperimen) yang menggunakan metode pembelajaran talking stick pada tes awal sebesar 2,33 dalam kategori cukup dan tes akhir sebesar 3,20 dengan (mengalami peningkatan dalam kategori mampu) setelah digunakan metode pembelajaran talking stick yang diterapkan dalam pembelajaran Bahasa Indonesia yaitu mengenai kemampuan menulis teks tanggapan kritis.

Dapat disimpulkan bahwa peserta didik kelas IX B yang bertindak selaku (kelompok kontrol) yang tidak dikenakan metode pembelajaran talking stick pada tes awal (pree-test) nilai rata-rata yang dicapai peserta didik sebesar 2,22 sedangkan pada kelas IX D yang bertindak selaku (kelompok eksperimen) sebelum dikenakan metode talking stick pada tes awal (pree-test) nilai rata-rata yang dicapai peserta didik sebesar 2,33, sehingga rentang nilai yang diperoleh pada kelas IX B selaku kelompok kontrol dan kelas IX D selaku kelompok eksperimen pada tes awal sebesar 11. Sedangkan nilai rata-rata yang diperoleh peserta didik pada test akhir pada kelas IX B selaku kelompok kontrol yang tidak dikenakan metode pembelajaran talking stick adalah 2,91 sedangkan kelas IX D selaku kelas eksperimen yang sudah diterapkannya metode pembelajaran talking stick nilai rata-rata yang di capai adalah 3,20 dapat disimpulkan bahwa rentang nilai yang diperoleh pada tes akhir adalah 29. Sehingga dapat dikatakan penggunaan metode pembelajaran talking stick efektif digunakan terhadap kemampuan menulis teks tanggapan kritis peserta didik kelas IX SMP Negeri 6 Wonomulyo.

\section{SARAN DAN REKOMENDASI}

Berdasarkan hasil penelitian yang telah dilaksanakan peneliti, ada beberapa saran yang dapat dikemukakan menyangkut pembelajaran menulis teks tanggapan kritis dengan menggunakan metode talking stick.

\section{Bagi pendidik}

Pendidik dalam hal ini guru, hendaknya mampu menciptakan suasana belajar yang dapat membuat peserta didik merasa senang dan lebih aktif dalam proses belajar mengajar, antara lain dengan menggunakan metode yang bervariasi salah satunya adalah dengan menggunakan metode talking stick dalam pembelajaran. 


\section{Bagi Peserta Didik}

Peserta didik hendaknya selalu bersikap aktif dalam proses pembelajaran di kelas, dan berusaha belajar bersungguh-sungguh sehingga hasil belajarnya dapat meningkat semaksimal mungkin.

\section{Bagi Pihak Sekolah}

Hendaknya seluruh pihak sekolah mendukung dalam kegiatan pembelajaran berlangsung dan menfasilitasi proses pembelajaran dengan melengkapi sarana dan prasarana sekolah.

\section{Bagi Peneliti Lanjutan}

Bagi peneliti lanjutan, hendaknya ketika melakukan penelitian perlu mengkaji lebih mendalam tidak hanya hasil belajar, namun disarankan dapat meneliti variabel lain seperti motivasi dan aktivitas peserta didik dari masingmasing metode pembelajaran.

\section{DAFTAR PUSTAKA}

Alwi, Hasan. Dkk. 2001. Tata Bahasa Baku Bahasa Indonesia: Edisi Ketiga. Jakarta: Balai Pustaka.

Enre, Fachruddin Ambo. 1994. Dasar-dasar Keterampilan Menulis. Ujung Pandang: IKIP Ujungpandang.

Dalman, H. 2015. Keterampilan Menulis. Jakarta: Rajawali Pers.

Djumingin, Sulastriningsih. 2011. Strategi dan Aplikasi Model Pembelajaran Inovatif Bahasa dan Sastra. Makassar: Badan Penerbit Universitas Negeri Makassar.

Iskandarwassid dan Sunendar, Dadang. 2008. Strategi Pembelajaran Bahasa. Bandung: Rosdakarya.

Tarigan, Henry Guntur. 2008. Menulis Sebagai Suatu Keterampilan Berbahasa. Bandung: Angkasa.

Zainurrahman. 2011. Menulis dari Teori Hingga Praktik (Penawar Racun Plagiarisme). Bandung: Alfabeta. 